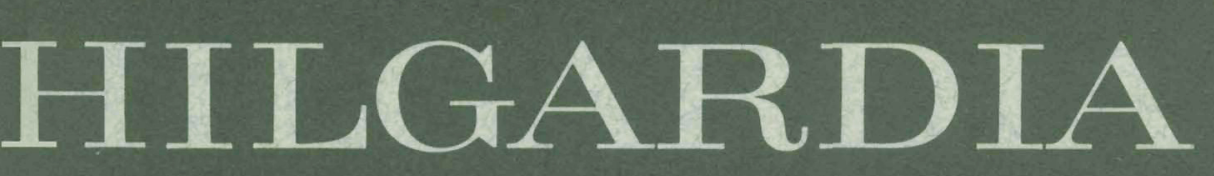

A JOURNAL OF AGRICULTURAL SCIENCE PUBLISHED BY THE CALIFORNIA AGRICULTURALEXPERIMENT STATION

Volume 38, Number $6 \cdot$ May, 1967

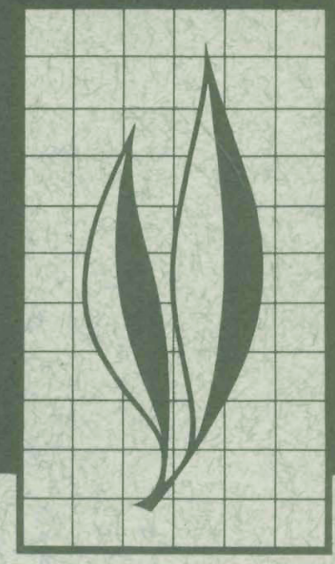

\title{
Creasing of Orange Fruit
}

W. W. Jones, T. W. Embleton, M. J. Garber, and C. B. Cree 


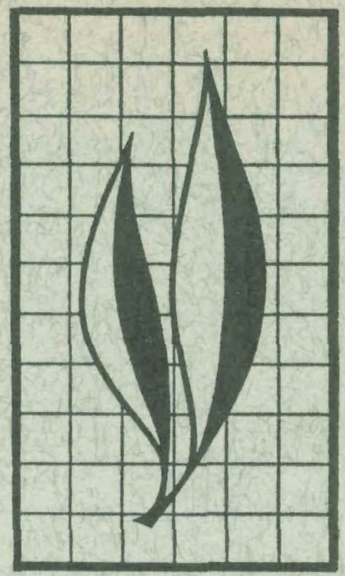

Several factors associated with creasing of oranges were observed and measured in a number of California field studies for more than a decade. Severity of creasing was found to be highly correlated with incidence. Creasing was highly variable among trees in a given orchard; occurred more frequently on the south half of the tree than on the north half; developed first on the side of the fruit facing the trunk; and became progressively more severe as the fruit aged. It was also associated with greater crop loads. Peel and juice composition were significantly different between creased and noncreased fruit from the same tree. Split or summer applications of nitrogen resulted in less creasing than spring applications; the effects of nitrogen rate were not consistent. Trees deficient in phosphorus in respect to volume yield produced fruit that had less creasing than phosphorus-sufficient trees, but the nutrient had no effect when applied beyond correction of the deficiency. Soil applications of potassium reduced creasing; potassium nitrate sprayed on foliage even after creasing was evident reduced creasing at harvest time. Over a ten-year period in one experiment, creasing was associated positively with the range between the mean minimum temperature for June and the mean maximum for July, also with the range between the mean minimum for December 15 to January 15 and the mean maximum for January 15 to February 15. Certain trees were consistently high in fruit yield and low in incidence of creasing. This suggests that a genetic factor might be influential.

\section{THE AUTHORS:}

W. W. Jones is Professor of Horticultural Science and Horticulturist in the Experiment Station, Riverside.

T. W. Embleton is Lecturer and Horticulturist in the Experiment Station, Riverside.

M. J. Garber is Professor of Biometry and Biometrician in the Experiment Station, Riverside.

C. B. Cree is Laboratory Technician IV, Department of Horticultural Science, Riverside. 


\section{Creasing of Orange Fruit ${ }^{1}$}

\section{INTRODUCTION}

"CREASING" in oranges intended for the fresh-fruit market causes considerable loss in California and other citrusproducing regions of the world. This peel defect-sometimes called puffing, grooving, wrinkle skin, or crinkly skin-affects Valencia, as well as all other orange varieties.

Rupture of the spongy flavedo tissue into irregular "creases" is caused by separation of cells in the albedo (fig. 1). When young, the cells in the albedo are thin-walled and approximately isodiametric; but as the fruit matures, these cells elongate, branch, and form an intricate network with large intercellular spaces (Bartholomew and Reed, 1946). ${ }^{2}$ As the peel ages, cell-branching can proliferate to such an extent that the cells separate completely, permitting the flavedo to crease. This occurs in delimited areas of the fruit, but has no specific orientation with respect to the fruit axis.

Creasing is sporadic, varying in incidence, degree, and location from year to year. The fundamental cause of creasing is unknown, but during the last decade or more, a number of factors have been observed and measured. These relationships are the subject of this report.

\section{REVIEW OF THE LITERATURE}

Peel defects in oranges have been recognized as a serious problem in California for at least sixty years (Pelton, 1907). Several workers have commented on creasing in connection with other studies. While no detailed morphological or physiological studies on creasing have been reported, Bartholomew and Reed (1946) indicated that it may result from the contraction both longitudinal and transverse, of the elongated and branched cells of the albedo, the cause of which is unknown. Charnat (1954) observed a much looser structure in the albedo of creased fruit as compared with noncreased fruit.

Generally, creasing is restricted to fruit with a thin peel; hence, those environmental, rootstock, and nutritional factors that tend to produce fruit with thin peels will increase the incidence of creasing, and, conversely, those that increase peel thickness will reduce creasing (Haas, 1950; Le Roux and Crous, 1938). La Roux and Crous (1938) and Fourie and Joubert (1957) observed that, in general, creasing occurred on the side of the fruit toward the center of the tree. Miller (1945) observed that the larger the crop, the greater the incidence of creasing, and that creasing was greater in the smaller fruit.

Le Roux and Crous (1938) reported that creasing was more severe on Mediterranean sweet orange than on other midseason varieties or on navel or Valencia oranges. Chevalier (1952) observed that Valencia Late and Vernia

\footnotetext{
${ }^{1}$ Submitted for publication May, 1966.

"See "Literature Cited" for citations referred to in text by author and date.
} 


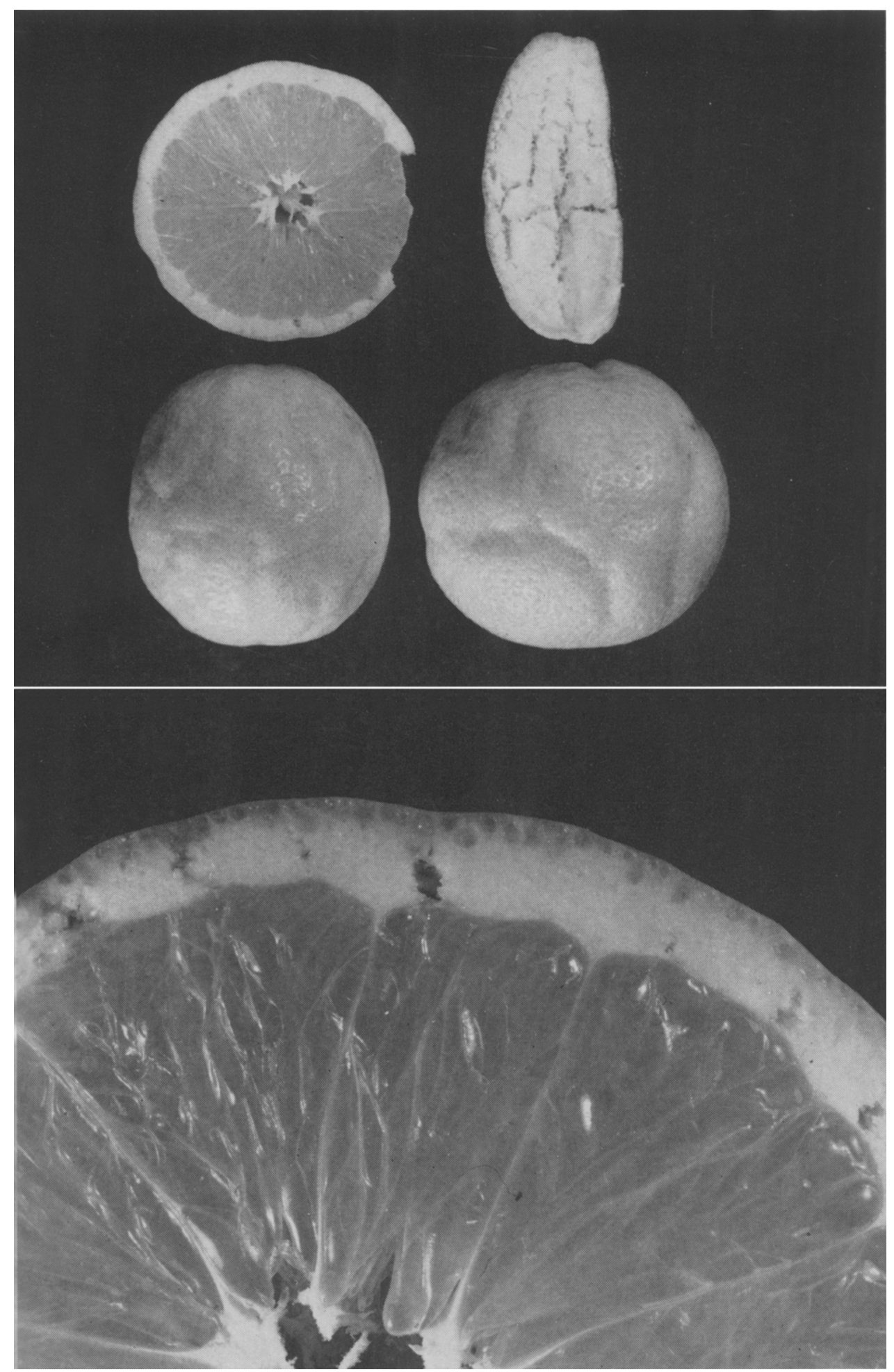

Fig. 1. Creasing in Valencia orange fruits. Note creases in the whole fruit and the broken albedo in the sections. In the whole fruit the creases occur over the broken areas of the albedo. 
varieties could remain on the tree for a long time without creasing, while other varieties that remained on the tree for a long time were more affected by creasing. Navel oranges, which remained on the tree for a shorter period of time, showed very little creasing. Observations from two areas in California on nine- to ten-year-old Valencia trees on Troyer citrange rootstock indicated that there was less split and creased fruit from the Cutter strain than from the Campbell old line or Frost nucellar in one location only (Lombard, 1963).

In Florida, Miller and Turnbull (1948) found more creasing on fruit from irrigated trees than from nonirrigated trees; the highest irrigation rate was associated with the most creasing. However, Le Roux and Crous (1938) observed no effect of irrigation on the incidence of creasing in South Africa tests. A considerable amount of creasing of Valencia oranges in a Florida experiment occurred in two out of five years. In one of those two years, low $\mathrm{N}$ treatments were associated with more creasing than were the intermediate or high rates (Reitz and Koo, 1960). Studies of Le Roux and Crous (1938) in South Africa also indicated that more creasing of Mediterranean sweet orange occurred with low than with high $\mathrm{N}$ rates.

Studies by Chapman and Rayner (1951), Fourie and Joubert (1957), and Le Roux and Crous (1938) suggest that $\mathrm{P}$ may be involved in creasing, but their data were not conclusive. In a culture solution experiment, Haas (1950) observed more creasing of Valencia oranges on Rough lemon rootstock with high than with low $\mathrm{P}$ rates.

A number of reports show that the incidence of creasing was reduced when the $\mathrm{K}$ level was increased (Chevalier, 1952; Fourie and Joubert, 1957; Reitz and Koo, 1960; Sites and Deszyck, 1952; van Niekerk, 1955). In the Sites and Deszyck (1952) study, there was essentially no creasing at the high $\mathrm{K}$ level, but grade was lowered because of an increase in coarseness of the peel.

\section{MATERIALS AND METHODS}

For over a decade the authors of this report have rated orange fruits for incidence of creasing in a number of California field studies on various factors of production. Incidence was rated visually on 100 random fruit, within easy reach from the ground, for each tree in each experiment and expressed as per cent of fruit that was creased. Severity of creasing was visually rated from 0 (no creasing) to 10 (100 per cent of fruit surface creased).
To compare the physcial and chemical characteristics with creased and noncreased fruits on the same tree, fruit samples were taken from a fertilizer experiment on Valencia oranges.

The data for these studies were obtained in per cent, transformed to angles for statistical analysis, and converted back to percentage of creasing for presentation (Snedecor, 1940). Where applicable, the data were evaluated by Duncan's (1955) multiple-range test.

\section{RESULTS AND DISCUSSION}

\section{Relation of incidence to severity of creasing}

At first, simple correlation studies were made to determine the relationship between severity and incidence of creas- ing. Table 1 indicates that fruit from trees with a large percentage of creased fruits had large portions of the surface areas affected. Since these correlations were very highly significant, only the 
TABLE 1

SIMPLE CORRELATION COEFFICIENTS (r) BETWEEN INCIDENCE AND SEVERITY OF CREASING IN VAIENCIA ORANGE FRUIT

\begin{tabular}{c|c|c}
\hline \hline Experiment & Number of trees* & $\mathrm{r} \dagger$ \\
\hline $1 \ldots \ldots \ldots \ldots \ldots \ldots \ldots$ & 108 & 0.67 \\
$2 \ldots \ldots \ldots \ldots \ldots \ldots \ldots$ & 240 & 0.90 \\
$3 \ldots \ldots \ldots \ldots \ldots \ldots \ldots$ & 240 & 0.74 \\
$4 \ldots \ldots \ldots \ldots \ldots \ldots \ldots$ & 270 & 0.86 \\
$5 \ldots \ldots \ldots \ldots \ldots \ldots$ & 260 & 0.87 \\
\hline
\end{tabular}

* One hundred fruits per tree reated for both incidence (percentage of fruit creased) and severity (rated as $0=$ no creasing and $10=100 \%$ of surface of fruit creased). Total number of fruit rated for data in table $1=111,800$.

$t$ All significant at the .001 level.
mer of

percentage figures on incidence are presented in the remainder of this report. Incidence of creasing is more readily determined in field studies than is severity, even though grading in the packing house is on the basis of severity.

\section{Variability of creasing}

In field studies on citrus, yields are usually more variable than other factors ordinarily measured (Jones, Embleton, and Cree, 1957). But the incidence of creasing is even more variable than yield. Using the coefficient of variability, we have found values from 9 to 85 per cent. The coefficient varies from year to year in a given location, and also varies from location to location in a given year. Generally, the coefficient ranges up to 60 per cent for a single year's data. This is in contrast with up to 30 per cent for yield and up to 5 per cent for total soluble solids (Jones, Embleton, and Cree, 1957). With such variability, the effects of nutritional treatments on the incidence of creasing are difficult to evaluate by analysis of variance, and in many instances correlation statistics have been used.

\section{Relation of tree sector and fruit orientation to creasing}

A three-year study on the relation of tree sector to creasing showed that,
TABLE 2

INFLUENCE OF POSITION OF THE

FRUIT IN RELATION TO TREE ON CREASING FROM A NUMBER OF EXPERIMENTS

\begin{tabular}{|c|c|c|c|c|}
\hline $\begin{array}{c}\text { Experi- } \\
\text { ment } \\
\text { number }\end{array}$ & $\begin{array}{l}\text { Date of } \\
\text { rating }\end{array}$ & $\begin{array}{c}\text { South } \\
\text { half of } \\
\text { tree }\end{array}$ & $\begin{array}{l}\text { North } \\
\text { half of } \\
\text { tree }\end{array}$ & $\begin{array}{l}\text { Signifi- } \\
\text { cance of } \\
\text { difference }\end{array}$ \\
\hline $1 \ldots$ & Oct., 1953 & $\begin{array}{c}\text { Per cent } \\
18\end{array}$ & $\begin{array}{c}\text { Per cent } \\
15\end{array}$ & NS \\
\hline $1 \ldots \ldots \ldots$ & April, 1954 & 22 & 8 & .01 \\
\hline $1 \ldots \ldots \ldots$ & April, 1955 & 48 & 44 & NS \\
\hline $2 \ldots$ & April, 1954 & 17 & 8 & .01 \\
\hline $2 \ldots$ & April, 1955 & 48 & 51 & NS \\
\hline $3 \ldots$ & April, 1954 & 16 & 6 & .01 \\
\hline $3 \ldots$ & April, 1955 & 49 & 43 & NS \\
\hline $4 \ldots$ & Sept., 1953 & 69 & 66 & NS \\
\hline $4 \ldots \ldots \ldots$ & Sept., 1954 & 12 & 7 & .01 \\
\hline $5 \ldots$ & Aug., 1954 & 54 & 37 & .01 \\
\hline
\end{tabular}

under southern California conditions, fruits on the south half of the tree were generally more severely creased than those on the north half, and were the first to show creasing (table 2).

On any given fruit, creasing develops first on the side toward the trunk, and thus is less severe on the exposed side of the fruit. This initial development of creasing is possibly related to the radial temperature gradient across the fruit, and hence to a differential water stress. This hypothesis needs to be evaluated critically.

\section{Relation of seasonal development to creasing}

Creasing is rarely detectable before the fruit reaches the legal standard of maturity. Creasing was rated three times each season in three successive years at one location, and twice each year for two years in a second location (table 3 ). The increase in percentage of fruit creased as the season progressed was consistently significant. As shown earlier, the severity of creasing is very highly correlated with the percentage of fruit creased. It is evident, therefore, that a delay in harvest will increase the cullage of fruits from orchards where creasing exists, since little creasing can be tolerated without loss of grade. 
TABLE 3

SEASONAL DEVELOPMENT OF CREASING IN ORANGES AT TWO LOCATIONS

\begin{tabular}{|c|c|c|c|c|c|}
\hline \multirow{3}{*}{ Season of rating* } & \multicolumn{5}{|c|}{ Fruit creased at: $\dagger$} \\
\hline & \multicolumn{3}{|c|}{ Location 1, Orange County } & \multicolumn{2}{|c|}{ Location 2, San Diego County } \\
\hline & 1962 & 1963 & 1964 & 1960 & 1961 \\
\hline & Per cent & Per cent & Per cent & Per cent & Per cent \\
\hline Early (April) .... & $15.1_{\mathrm{y}}$ & $6.1 \mathbf{x}$ & $6.4 \mathrm{x}$ & $51.9 y$ & $11.2 \mathrm{y}$ \\
\hline Mid (July) ............ & $17.2 \mathrm{y}$ & $14.9 y$ & $23.3_{y}$ & $\ldots$ & $\ldots$ \\
\hline Late (September). & $25.5 \mathrm{z}$ & $25.2 \mathrm{z}$ & $58.0 \mathrm{z}$ & $75.4 \mathrm{z}$ & $58.2_{x}$ \\
\hline
\end{tabular}

* Same fruit rated for per cent of creasing during the season.

$\dagger$ Ranked at the .01 level. Means are significantly different if they do not have a subscript letter in common. Each value for Location 1 is the mean for 5,400 fruit; each value for Location 2 is the mean for 9,600 fruit.

\section{Relation of creased and noncreased fruit from the same trees}

Creased fruit are significantly different from noncreased fruit in most of the composition factors reported in table 4 . The peel of the creased fruit ( significantly thinner than that of the noncreased fruit) contained more $\mathrm{K}$ (in both $+\mathrm{K}$ and $-\mathrm{K}$ treatments) than did that of the noncreased; yet, as will be shown later, the application of $\mathrm{K}$ fertilizers to these same trees decreased creasing. Generally, $\mathrm{K}$ fertilizers increase peel thickness of oranges (Reuther and Smith, 1952). Thus, creasing is apparently related to peel thickness and not to $\mathrm{K}$ content of tissue, per se, but just why the thinner peels are higher in $\mathrm{K}$ is not clear.

The lower acid content suggests that

TABLE 4

JUICE AND PEEL CHARACTERISTICS OF VALENCIA ORANGES AS RELATED TO CREASING

\begin{tabular}{|c|c|c|c|}
\hline \multirow{2}{*}{ Factor } & \multicolumn{2}{|c|}{ Fruit* } & \multirow{2}{*}{$\begin{array}{l}\text { Significance } \\
\text { of difference }\end{array}$} \\
\hline & Noncreased & Creased & \\
\hline Specific gravity of fruit $\ldots \ldots \ldots \ldots \ldots \ldots \ldots \ldots$ & 0.891 & 0.903 & .01 \\
\hline 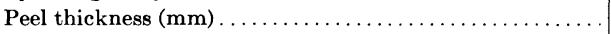 & 5.1 & 4.4 & .01 \\
\hline Juice, per cent $(w / w) \ldots \ldots \ldots \ldots \ldots \ldots$ & 51.8 & 55.4 & .01 \\
\hline \multicolumn{4}{|l|}{ Juice composition: } \\
\hline Acid, per cent ( $w / w)$. & 1.28 & 1.13 & .01 \\
\hline Soluble solids, per cent $(w / w) \ldots \ldots \ldots \ldots \ldots \ldots$ & 12.2 & 12.1 & NS \\
\hline SS/acid (ratio) $\ldots \ldots \ldots \ldots \ldots \ldots \ldots \ldots \ldots \ldots \ldots \ldots$ & 9.39 & 10.79 & .01 \\
\hline Ascorbic acid $(\mathrm{mg} / 100 \mathrm{ml}) \ldots \ldots \ldots \ldots \ldots$ & 67.0 & 64.1 & .05 \\
\hline $\mathrm{N} \quad(\mathrm{mg} / 100 \mathrm{ml}) \ldots \ldots \ldots \ldots$ & 100.0 & 101.0 & NS \\
\hline$P \quad(\mathrm{mg} / 100 \mathrm{ml}) \ldots \ldots \ldots$ & 4.57 & 4.96 & NS \\
\hline 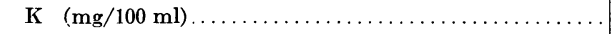 & 149.0 & 137.0 & .01 \\
\hline $\mathrm{Ca}(\mathrm{mg} / 100 \mathrm{ml}) \ldots \ldots \ldots \ldots$ & 3.91 & 4.04 & NS \\
\hline 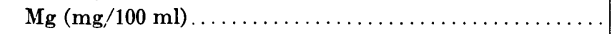 & 3.78 & 3.02 & .01 \\
\hline 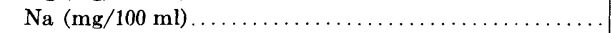 & 4.35 & 5.36 & .01 \\
\hline \multicolumn{4}{|l|}{ Peel composition: } \\
\hline $\mathrm{N}$ per cent (dry wt.). & 1.62 & 1.66 & .05 \\
\hline P per cent (dry wt.). . & 0.057 & 0.061 & .01 \\
\hline $\mathrm{K}$ per cent (dry wt.)... & 0.74 & 0.79 & .01 \\
\hline Ca per cent (dry wt.).... & 0.44 & 0.35 & .01 \\
\hline 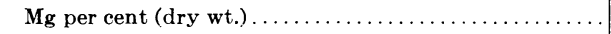 & 0.090 & 0.079 & .01 \\
\hline 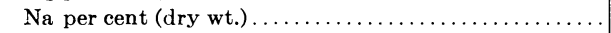 & 0.016 & 0.009 & .01 \\
\hline
\end{tabular}

* Fruit sampled May, 1954. Each value is the mean of 53 plots. Fruit sampled were of size 200 fruits per packed box (av. dia. 2.76 inches). 
TABLE 5

THE INTERACTION OF N AND K ON CREASING OF VALENCIA ORANGES*

(Orange County, 1953 to 1956, inclusive)

\begin{tabular}{|c|c|c|c|c|}
\hline \multirow{2}{*}{$\mathrm{N}$ treatment $\dagger$} & \multicolumn{3}{|c|}{$\mathrm{K}$ treatment } & \multirow{2}{*}{$\begin{array}{c}\text { Signifi- } \\
\text { cance } \\
\text { of } K\end{array}$} \\
\hline & $\mathrm{K}_{0}$ & $\mathrm{~K}_{1}$ & $\mathrm{~K}_{2}$ & \\
\hline & \multicolumn{3}{|c|}{ Per cent of fruit creased } & \\
\hline No.. & $41.9_{z}^{z}$ & $43.0_{z}^{z}$ & $31.5^{\mathrm{y}}$ & .05 \\
\hline $\mathrm{N}_{1} \ldots$ & $39.5 z$ & $31.2 y$ & 33.3 & NS \\
\hline $\mathrm{N}_{2} \ldots \ldots$ & $28.7 y$ & $35.4 y z$ & 34.5 & NS \\
\hline Significance of $N$ & .05 & .05 & NS & \\
\hline
\end{tabular}

* There were four replications of this factorial experiment with four trees per plot. Compare subscript letters vertically for $\mathrm{N}$ effects; means are significantly different if they do not have a subscript letter in common. Compare superscript letters horizontally for K effects; means are significantly different if they do not have a superscript letter in common.

+ The experimental treatments were superimposed upon the normal ranch application which was about 2.5 lb. $\mathrm{N}$ per tree annually.

the creased fruit are more mature than the noncreased.

Many differences are evident between creased and noncreased fruit, but the data offer no explanation as to why some fruit on a tree crease and others on the same tree do not.

\section{Influence of nitrogen, phosphorus, and potassium on creasing}

Fruit creasing was rated in a number of fertilizer experiments which were designed to relate nutritional requirements and leaf analysis to fruit production and fruit quality. Only the creasing data are treated here.

NK interaction and nitrogen rate. In 1950 , a $3 \times 3$ NK factorial experiment was established in Orange County. Treatments were superimposed on the regular ranch treatment in 1950 and 1951. Application rates for $\mathrm{N}$ were 0 (control), 1.5, and 3 pounds per tree; for $\mathrm{K}$ (broadeast as $\mathrm{K}_{2} \mathrm{SO}_{4}$ ), 0 (control), 4.5, and 27 pounds per tree. Potassium treatments increased $\mathrm{K}$ in the leaves only slightly. There were no significant effects on fruit yield. Creasing was determined in September or October each year from 1953 to 1956, inclusive. The interaction of $\mathrm{N}$ and $\mathrm{K}$ on creasing is shown in table 5 . These data show that an increase in $\mathrm{N}$ rate reduced creasing when no $\mathrm{K}$ was applied, but did not significantly affect creasing at the high rate of $K$. Also, a substantial increase in the $\mathrm{K}$ rate reduced creasing only when no experimental $\mathrm{N}$ was applied. Additive effects of $\mathrm{N}$ and $\mathrm{K}$ on creasing were not indicated in this experiment.

Another experiment with Valencia oranges, established in Orange County

TABle 6

EFFECTS OF N TREATMENTS ON CREASING OF VALENCIA ORANGES

(Orange County, 1955 to 1960 , inclusive)

\begin{tabular}{|c|c|c|c|c|c|c|}
\hline \multirow{2}{*}{ Treatment* } & \multicolumn{6}{|c|}{ Creasing $\dagger$} \\
\hline & 1955 & 1956 & 1957 & 1958 & 1959 & 1960 \\
\hline & Per cent & Per cent & Per cent & Per cent & Per cent & Percent \\
\hline 1. Control. & 63.8 & 29.8 & 6.2 & 19.0 & $35.9 y$ & $35.8_{z}$ \\
\hline 2. One urea spray (February)... & 60.1 & 26.0 & 7.1 & 14.8 & $49.8 \mathrm{y} \mathrm{z}$ & $21.0 \mathrm{yz}$ \\
\hline 3. Same as 2, plus $1.67 \mathrm{lb}$. $\mathrm{N}$ on soil (February). & 61.1 & 22.4 & 13.0 & 13.3 & $48.6 \mathrm{y} \mathrm{z}$ & $17.7 \mathrm{y}$ \\
\hline 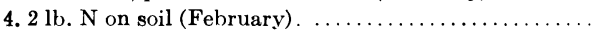 & 62.6 & 15.5 & 10.1 & 22.9 & $55.9 \mathrm{y} \mathrm{z}$ & $16.6 \mathrm{y}$ \\
\hline 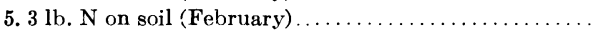 & 64.6 & 24.3 & 7.0 & 17.4 & $55.5 \mathrm{yz}$ & $17.9 \mathrm{y}$ \\
\hline 6. Three urea sprays (February, May, July) .......... & 55.1 & 21.7 & 9.0 & 11.0 & $65.6 \mathrm{z}$ & $23.1_{\mathrm{yz}}$ \\
\hline 7. Same as 6 , plus $2 \mathrm{lb} . \mathrm{N}$ on soil (February) ........... & 57.6 & 15.3 & 9.8 & 14.1 & $61.4 \mathrm{z}$ & $14.4 \mathrm{y}$ \\
\hline Significance of difference. & NS & NS & NS & NS & .01 & .05 \\
\hline 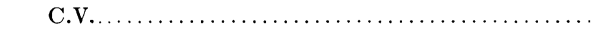 & 9.6 & 16.1 & 19.5 & 27.1 & 11.8 & 21.9 \\
\hline
\end{tabular}

* Treatments were applied on four replications of four trees per plot. Concentration of urea in sprays was $10 \mathrm{lb}$. per 100 gal. In addition, each tree received about $0.5 \mathrm{lb} . \mathrm{N}$ annually from the irrigation water.

$\dagger$ Means are significantly different at the level indicated if they do not have a subscript letter in common. 
TABLE 7

EFFECTS OF N TREATMENTS ON CREASING OF WASHINGTON NAVEL ORANGES

(Tulare County, 1957 and 1958)

\begin{tabular}{|c|c|}
\hline Treatments* & $\begin{array}{l}\text { Fruits creased } \\
\text { (av. of 1957 } \\
\text { and 1958) } \dagger\end{array}$ \\
\hline & Per cent \\
\hline \multicolumn{2}{|l|}{ February: } \\
\hline $0.5 \mathrm{lb} . \mathrm{N}$ per tree $\ldots \ldots \ldots \ldots \ldots$ & $10.0 y$ \\
\hline 1 lb. $\mathrm{N}$ per tree............. & $20.7 z$ \\
\hline $2 \mathrm{lb} . \mathrm{N}$ per tree.... & $13.7 \mathrm{yz}$ \\
\hline $4 \mathrm{lb} . \mathrm{N}$ per tree...... & $5.6 y$ \\
\hline \multicolumn{2}{|l|}{ Spring, summer, fall (split): } \\
\hline 2 lb. $\mathrm{N}$ per tree............. & $7.6 y$ \\
\hline Significance of difference. . & .05 \\
\hline C.V................. & 19.5 \\
\hline
\end{tabular}

${ }^{*} \mathrm{~N}$ was supplied from $\mathrm{Ca}\left(\mathrm{NO}_{3}\right)_{2}$ and applied on four replications of four trees per plot.

$\dagger$ Means are significantly different at the level indicated if they do not have a subscript letter in common.

in 1950, showed that $\mathrm{N}$ treatments had no significant effects on fruit yield. The effects of $\mathrm{N}$ treatments on creasing were not consistent from year to year, and in only two of the six years were they significant (table 6 ).

In 1954, an $\mathrm{N}$ experiment was initiated on Washington navel oranges in Tulare County (table 7). In 1957 and 1958 creasing occurred in amounts worth rating, but yields were not significantly different as a result of treatments. Although there appear to be significant effects of $\mathrm{N}$ rates and timing on creasing, clear conclusions are not discernible because of certain anomalies in treatment effects.

In 1953, another $\mathrm{N}$ experiment with Valencia oranges was established in San Diego County (table 8). Creasing was rated in the March-April period each year from 1954 to 1962 . Among the urea-sprayed plots, significantly less creasing occurred in the one treated annually in July, August, and November. However, this particular treatment resulted in low fruit yield, which, in turn, could account for the low incidence of creasing. Among the soil treatments, 1 pound of $\mathrm{N}$ per tree annually produced less creasing than did 2 pounds. Split
TARLE 8

EFFECTS OF N TREATMENTS ON CREASING OF VALENCIA ORANGES* (San Diego County, 1954 to 1962, inclusive)

\begin{tabular}{|c|c|}
\hline Annual treatments & $\begin{array}{c}\text { Fruit } \\
\text { creased } \dagger\end{array}$ \\
\hline & Per cent \\
\hline \multicolumn{2}{|l|}{ Spray (urea): } \\
\hline 1. Three, Feb., April, May.............. & $24.6 \mathrm{y}$ \\
\hline 2. Three, July, Aug., Nov... & $12.6 \mathrm{x}$ \\
\hline 3. Three, Feb., May, Aug.............. & $24.2 \mathrm{y}$ \\
\hline Soil $(N)$ : & \\
\hline 4. 1 lb. (from $\mathrm{Ca}\left(\mathrm{NO}_{3}\right)_{2}$ ) split, Feb., May, & \\
\hline Aug $\ldots \ldots \ldots \ldots \ldots \ldots \ldots \ldots \ldots \ldots \ldots \ldots$ & $25.4 y$ \\
\hline 5. 1 lb. (from urea) split, Feb., May, Aug... & $23.6 \mathrm{y}$ \\
\hline 6. 2 lh. (from $\left.\mathrm{Ca}\left(\mathrm{NO}_{3}\right)_{2}\right)$ split, Feb., May, & \\
\hline 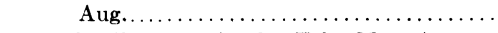 & $31.8 \mathrm{yz}$ \\
\hline 7. 2 lb. (from urea) split, Feb., May, Aug... & $31.8 \mathrm{yz}$ \\
\hline 8. 2 lb. (from $\left.\mathrm{Ca}\left(\mathrm{NO}_{3}\right)_{2}\right)$ Feb............. & $41.3_{\mathrm{z}}$ \\
\hline 9. 2 lb. (from urea) Feb............ & $37.2 \mathrm{y} \mathrm{z}$ \\
\hline 10. $2 \mathrm{lb}$. (from $\left.\mathrm{Ca}\left(\mathrm{NO}_{3}\right)_{2}\right)$ July .......... & $23.6 \mathrm{y}$ \\
\hline Significance of difference........ & .01 \\
\hline 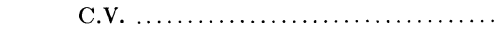 & 42.7 \\
\hline \multicolumn{2}{|l|}{ Single degree-of-freedom comparisons: } \\
\hline $1 \mathrm{lb} . \mathrm{N}$, split $(4$ and 5$) \ldots \ldots \ldots \ldots \ldots \ldots$ & 24.4 \\
\hline 2 lb. $N$, split $(6$ and 7$) \ldots \ldots \ldots \ldots \ldots$ & 31.8 \\
\hline Significance of difference $\ldots \ldots \ldots \ldots \ldots$ & .05 \\
\hline 2 lb. N, Feb. (8 and 9$).$ & 39.2 \\
\hline 2 lb. $N$, split ( 6 and 7$) \ldots \ldots$ & 31.8 \\
\hline Significance of difference............ & .05 \\
\hline 2 lb. N, Feb. ( 8 and 9$).$ & 39.2 \\
\hline 2 lb. N, July $(10) \ldots \ldots \ldots \ldots \ldots \ldots \ldots \ldots \ldots$ & 23.6 \\
\hline Significance of difference $\ldots \ldots \ldots \ldots \ldots$ & .001 \\
\hline $\mathrm{Ca}\left(\mathrm{NO}_{3}\right)_{2}(4,6$, and 8$)$. & 32.6 \\
\hline Urea $(5,7$, and 9$) \ldots \ldots \ldots \ldots$ & 30.7 \\
\hline Significance of difference... & NS \\
\hline
\end{tabular}

* Experiments were conducted on five replications of single-tree plots.

$\dagger$ Where ranked, means are significantly different at the .01 level if they do not have a subscript letter in common.

applications of $\mathrm{N}$ resulted in less creasing than did single applications of $\mathrm{N}$ in February. No significant differences occurred between effects of $\mathrm{Ca}\left(\mathrm{NO}_{3}\right)_{2}$ and urea on incidence of creasing.

Data from these experiments show no consistent effects of $\mathrm{N}$ rate on creasing. The data suggest, however, that spring (February) applications of $\mathrm{N}$ resulted in more creasing than did either split or single application in the summer.

$\mathbf{P}, \mathbf{K}$, dolomite, and $\mathbf{P} \times \mathbf{K}$ interaction. Creasing was rated in the March-April period annually in a factorial $\mathrm{P}, \mathrm{K}$, and 
TABLE 9

MAIN EFFECTS OF P AND K ON CREASING OF VALENCIA ORANGES* (San Diego County)

\begin{tabular}{|c|c|c|c|c|c|c|c|c|c|c|}
\hline \multirow{2}{*}{ Treatment } & \multicolumn{10}{|c|}{ Creasing } \\
\hline & 1953 & 1954 & 1955 & 1956 & 1957 & 1958 & 1959 & 1960 & 1961 & 1962 \\
\hline & Per cent & Percent & Percent & Percent & Percent & Percent & Percent & Percent & Percent & Percent \\
\hline $\mathrm{P}_{0} \ldots \ldots$ & 2.5 & 7.6 & 38.7 & 9.9 & 2.0 & 2.1 & 13.1 & 44.2 & 17.5 & 6.8 \\
\hline$P_{1} \ldots \ldots \ldots \ldots \ldots \ldots \ldots \ldots \ldots \ldots \ldots$ & 28.6 & 20.1 & 52.7 & 30.8 & 11.3 & 7.6 & 28.6 & 44.6 & 63.6 & 8.6 \\
\hline Significance of difference........ & .001 & .001 & .01 & .001 & .001 & .001 & .001 & NS & .001 & NS \\
\hline $\mathbf{K}_{0} \ldots \ldots \ldots$ & 16.5 & 14.0 & 50.2 & 25.2 & 8.7 & 5.4 & 23.7 & 53.2 & 43.5 & 8.8 \\
\hline $\mathbf{K}_{\mathbf{1}} \ldots \ldots \ldots \ldots \ldots$ & 9.1 & 12.5 & 41.2 & 13.9 & 3.5 & 3.5 & 17.1 & 35.8 & 26.8 & 6.7 \\
\hline Significance of difference........ & .001 & NS & NS & .001 & .001 & .05 & .01 & .01 & .01 & NS \\
\hline C.V... & 23.0 & 29.1 & 24.4 & 27.5 & 49.3 & 37.3 & 35.1 & 40.4 & 18.3 & 54.1 \\
\hline
\end{tabular}

* Twenty fruit per tree were rated for creasing from 1953 to $1956 ; 100$ per tree thereafter. The factorial $(2 \times 2 \times 3, \mathrm{P} \times$ $\mathrm{K} \times$ dolomite) consisted of two trees per plot on each of five replications. (Dolomite showed no significant effects on creasing).

dolomite experiment from 1953 to 1962 in which $\mathrm{P}$ and $\mathrm{K}$ were increased in the leaves by their respective treatments. Dolomite had no significant effect on creasing. The main effects of $\mathrm{P}$ and $\mathrm{K}$ are presented in table 9 and show that soil application of $\mathrm{P}$ increased creasing, and soil application of $\mathrm{K}$ reduced it.

There was a highly significant interaction between $\mathrm{P}$ and $\mathrm{K}$ on creasing (data not presented). Where $\mathrm{P}$ was not applied fruit yield was limited by $\mathrm{P}$ deficiency (Embleton, Jones, and Kirkpatrick, 1956; Embleton, Kirkpatrick, Jones, and Cree, 1956; Embleton, Kirkpatrick, and Parker, 1952). Potassium application to such P-deficient trees had less influence on reducing creasing than where $\mathrm{P}$ was applied.

$\mathbf{P}$ rates. Starting with $\mathrm{P}$-deficient trees, $\mathrm{P}$ was applied in 1951 only at the rate of 0 (control), 2, 4, or 8 pounds per tree on two-tree plots with five replications. In other treatments, the same rates of $\mathrm{P}$ were applied annually from 1951 to 1958 , for a total of 16,32 , or 64 pounds per tree. Creasing was rated ontree in the March-April period for the years 1953 , and 1955 to 1959 . The results for the combined six-year period are shown in table 10.

Haas (1950) reported that $\mathrm{P}$ was associated with creasing. In the $\mathrm{P}, \mathrm{K}$, and
TABLE 10

INFLUENCE OF INCREASING PHOSPHORUS RATES ON CREASING AND AMOUNT OF PHOSPHORUS IN LEAVES OF VALENCIA ORANGES*

\begin{tabular}{|c|c|c|}
\hline \multirow{2}{*}{$\mathrm{P}$ application } & \multicolumn{2}{|c|}{ Effects on: } \\
\hline & $\underset{\text { creasing } \dagger}{\text { Fruit }}$ & $\begin{array}{l}P \text { content } \\
\text { in leavesł }\end{array}$ \\
\hline 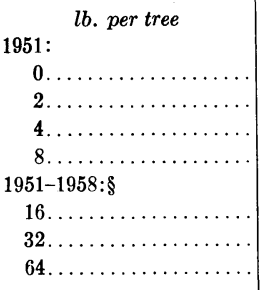 & $\begin{array}{l}\text { Per cent } \\
\qquad \begin{array}{l}12.7_{\mathrm{y}} \\
27.1_{\mathrm{y} z} \\
38.8_{\mathrm{z}} \\
40.1_{\mathrm{z}} \\
\\
39.2_{\mathrm{z}} \\
38.9_{\mathrm{z}} \\
44.2_{\mathrm{z}}\end{array}\end{array}$ & $\begin{array}{l}\text { Per cent } \\
0.115_{\mathrm{w}} \\
0.126_{\mathrm{x}} \\
0.127_{\mathrm{x}} \\
0.126_{\mathrm{x}} \\
0.146_{\mathrm{y}} \\
0.152_{\mathrm{y}} \\
0.191_{\mathrm{z}}\end{array}$ \\
\hline 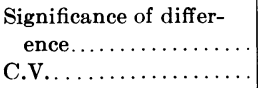 & $\begin{array}{c}.01 \\
39.6\end{array}$ & $\begin{array}{r}.01 \\
10.7\end{array}$ \\
\hline
\end{tabular}

* Experiments were conducted on two-tree plots with five replications.

t Mean values for March-April period of 1953 and 1955 to 1959. Values are significantly different if there are no subscript letters in common.

† Sample from nonfruiting spring-cycle terminals in August, 1958. Ranked at .05.

$\S$ Applied at the rate of 2,4 , or $8 \mathrm{lb}$. per tree annually.

dolomite experiment reported above, $\mathbf{P}$ did indeed increase creasing. However, in the $\mathrm{P}$-rate experiment, the $\mathrm{P}$ in leaves was increased well above the minimum level required for maximum yield; yet the statistically significant increase in creasing occurred only as the $\mathrm{P}$ was increased from a deficiency (for 
TABLE 11

INFLUENCE OF $\mathrm{KNO}_{3}$ FOLIAGE SPRAYS AND $\mathrm{K}_{2} \mathrm{SO}_{4}$ SOIL APPLICATIONS ON LEAF COMPOSITION AND CREASING OF VALENCIA ORANGES

\begin{tabular}{|c|c|c|c|c|}
\hline \multirow{3}{*}{ Treatment } & \multicolumn{3}{|c|}{ Leaf samples analyzed: } & \multirow{2}{*}{$\begin{array}{l}\text { Fruit } \\
\text { creasing } \\
\text { noted: }\end{array}$} \\
\hline & $\underset{\text { (pre-treatment) }}{\text { For K }}$ & $\begin{array}{c}\text { For N } \\
\text { (post-treatment) }\end{array}$ & $\underset{\text { (post-treatment) }}{\text { For K }}$ & \\
\hline & $10 / 17 / 63$ & $3 / 30 / 64$ & $3 / 30 / 64$ & $7 / 15 / 64$ \\
\hline 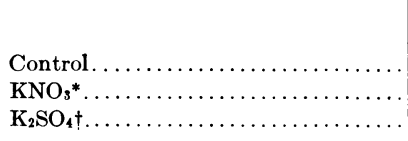 & $\begin{array}{c}\text { Per cent } \\
\\
\quad 0.46 \\
0.45 \\
0.44\end{array}$ & 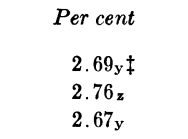 & $\begin{array}{c}\text { Per cent } \\
0.34_{\mathrm{y}} \ddagger \\
0.54_{\mathrm{z}} \\
0.34_{\mathrm{y}}\end{array}$ & $\begin{array}{c}\text { Per cent } \\
42.6 \text { z } \\
27.2 y \\
38.1\end{array}$ \\
\hline $\begin{array}{l}\text { Significance of difference } \ldots \ldots \ldots \ldots \ldots \\
\text { C.V. } \ldots \ldots \ldots \ldots \ldots \ldots \ldots \ldots \ldots \ldots\end{array}$ & $\begin{array}{l}\text { NS } \\
\ldots\end{array}$ & $\begin{array}{l}.01 \\
3.9\end{array}$ & $\begin{array}{l}.01 \\
4.9\end{array}$ & $\begin{array}{r}.01 \\
27.0\end{array}$ \\
\hline
\end{tabular}

* KNOs at 40 lb. $/ 100$ gal. applied as foliage spray on March 11 and May 9, 1964.

$+\mathrm{K}_{2} \mathrm{SO}_{4}$ applied at $9 \mathrm{lb}$. K/tree broadcast on the soil, March 11, 1964.

$\ddagger$ Significantly different if there are no subscript letters in common.

fruit yield) to a minimum adequate level. Since an adequate level of P must be maintained for production, it is evident that $\mathrm{P}$ had no effect of commercial importance in this experiment.

$\mathrm{KNO}_{3}$ foliage sprays. A $2 \times 3 \mathrm{PK}$ factorial, consisting of six treatments with 15 replications of single-tree plots was started in March, 1964. Since the main effects of $\mathrm{P}$ and the $\mathrm{P} \times \mathrm{K}$ interaction were not significant, only the main effects of $\mathrm{KNO}_{3}$ and $\mathrm{K}_{2} \mathrm{SO}_{4}$ treatments are considered here. Treatments were: (1) $\mathrm{K}_{0}$ (control), (2) $40 \mathrm{lb} . \mathrm{KNO}_{3} / 100$ gal. water applied as a foliage spray, and (3) $9 \mathrm{lb}$./tree of $\mathrm{K}$ as $\mathrm{K}_{2} \mathrm{SO}_{4}$ applied on the soil. The first applications were made on March 11, 1964; $\mathrm{KNO}_{3}$ sprays were applied again on May 19, 1964. Pretreatment leaf samples were obtained on October 17, 1963, and posttreatment samples were taken on March 30,1964 . Creasing was rated on trees on July 15, 1964. Results of leaf analysis and creasing ratings are presented in table 11.

Creasing was significantly reduced by the $\mathrm{KNO}_{3}$ foliage sprays even though some creasing was evident at the time of spray application. As already reported, creasing varies from season to season and increases from the beginning to the end of the harvest season. Since the $\mathrm{KNO}_{3}$ sprays are rapidly effective, it appears possible to delay treatment until evidence indicates that creasing will be an economic problem for the current season.

Even though potassium sulfate soil applications had no significant influence on creasing in this experiment, it is clear in the section on $\mathrm{P}, \mathrm{K}$, dolomite and $\mathrm{P} \times \mathrm{K}$ interaction that soil applications of $\mathrm{K}$ were effective in reducing creasing after sufficient time elapsed for adequate absorption of $\mathrm{K}$ by the tree.

\section{Relation of temperature to creasing}

Data were obtained on creasing-temperature relations from San Diego County. Creasing percentage was determined on 27 trees each year for a period of 10 seasons (1952-1953 to 1961-1962), along with daily temperature records. After adjustment for number of fruit per tree, correlation analyses were made with various periods of the year and various aspects of temperature. The only aspect of temperature significantly correlated with creasing was found to be the range between minimum and maximum for two specific periods (fig. 2). The first period (range 1) considered the range between the mean minimum for June and the 


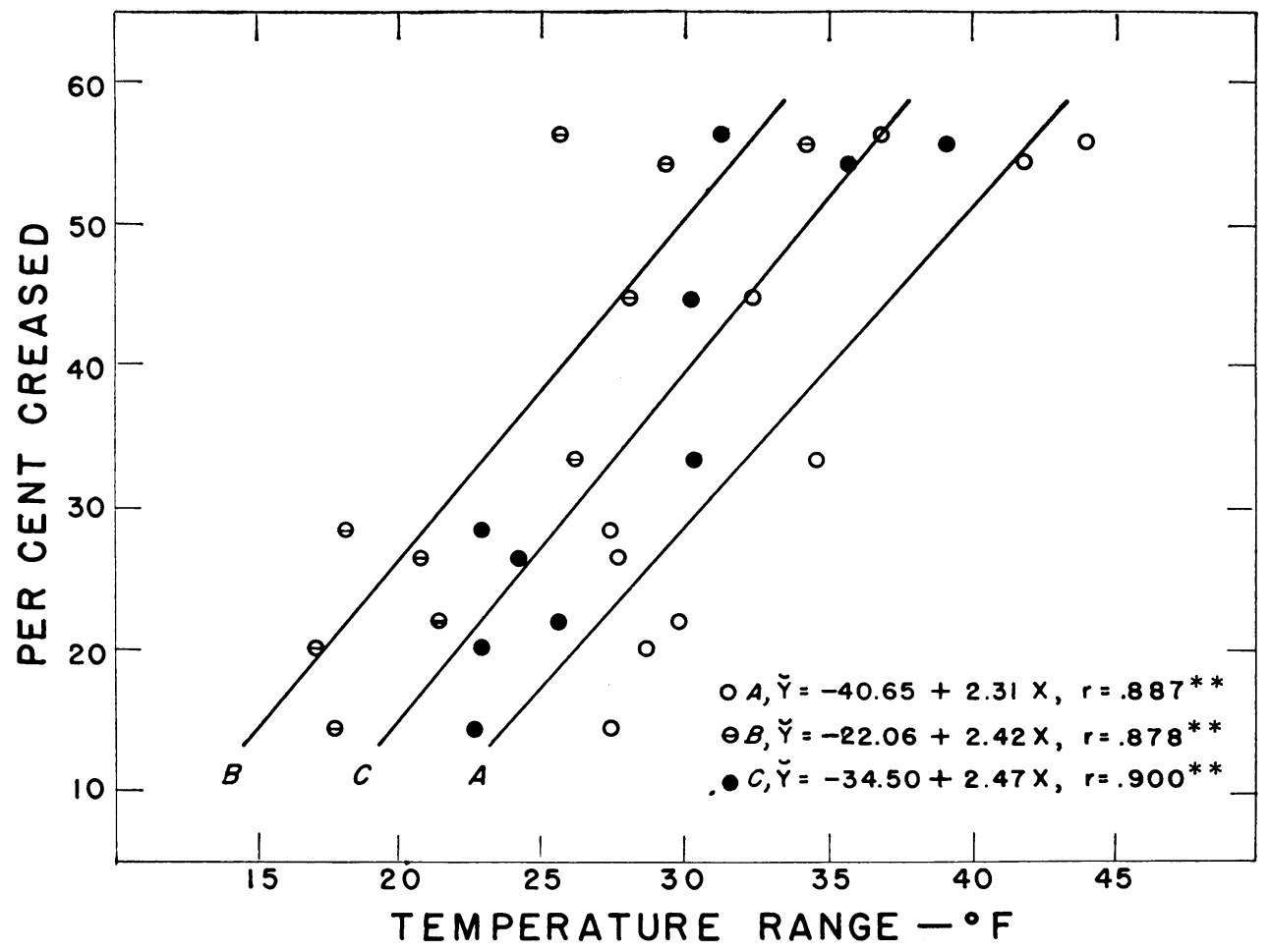

Fig. 2. Relation of temperature to creasing of Valencia oranges in San Diego County, California. Range $1(A)=$ the range between the mean minimum for June and the mean maximum for July. Range $2(B)=$ the range between the mean minimum for December 15 to January 15 and the mean maximum for January 15 to February 15. C combines A and B.

mean maximum for July. This is the period of "June drop" and early growth of the fruit that remains on the tree. This early growth occurs by cell division and enlargement (Bain, 1958). The second period (range 2) comes later in the life of the fruit and is the range between mean minimum for December 15 to January 15 and mean maximum for for January 15 to February 15. Again, growth is mostly by cell enlargement (Bain, 1958). The correlation is slightly improved when the two periods are combined (see fig. 2). The partial correlations were not significant, indicating that either period is important in conditioning the fruit for creasing. Just why these two periods are critical is not clear-an explanation awaits a better understanding of the morphological changes in the peel associated with creasing. The cells of the albedo, especially during the second period, become branched (Bain, 1958) and entwined. Probably entwinement is reduced by a wide temperature range, and thus the ability of the albedo to withstand stress (probably water) is reduced. In any case, the range in temperature, and not temperature per se is apparently related to creasing.

\section{Correlation studies}

When $\mathrm{P}$ was deficient in a San Diego County experiment, applications of this element had a marked effect on yield, fruit size, fruit quality, and fruit and leaf composition. Under these conditions, simple correlations between creasing and most of the variables (including factors of yield, fruit size, fruit quality, and fruit and leaf composition) were 


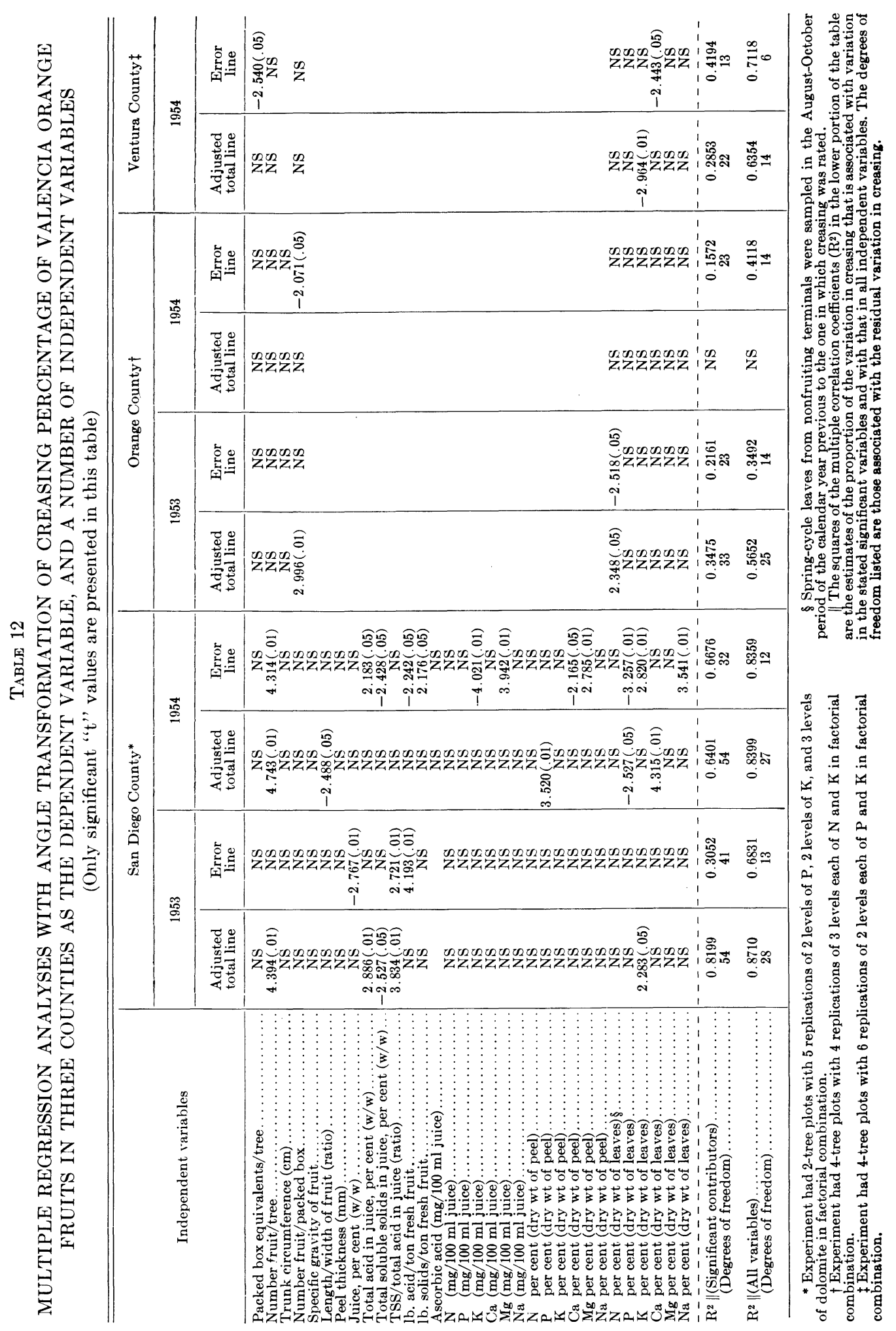


TABLE 13

MEAN CREASING AND YIELD RELATIONS FROM 27 UNIFORMLY TREATED VALENCIA ORANGE TREES

(SAN DIEGO COUNTY, 1954 TO 1963)

\begin{tabular}{|c|c|c|c|c|c|c|}
\hline \multirow{3}{*}{ Tree no. } & \multicolumn{4}{|c|}{ Creasing } & \multirow{2}{*}{\multicolumn{2}{|c|}{ Yield }} \\
\hline & \multicolumn{2}{|c|}{ Unadjusted } & \multicolumn{2}{|c|}{ Adjusted } & & \\
\hline & $\underset{\text { rank }}{\text { Numerical }}$ & Per cent & $\begin{array}{c}\text { Numerical } \\
\text { rank }\end{array}$ & Per cent & $\begin{array}{c}\text { Numerical } \\
\text { rank }\end{array}$ & No. fruit/tree/year \\
\hline $14-3-N \ldots$ & 1 & $12.2^{*} *$ & 1 & $14.4 \mathrm{~s}^{*}$ & 7 & 1150 qrstur ${ }^{*}$ \\
\hline $14-5-S \ldots \ldots$ & 2 & $21.5_{\mathrm{st}}$ & 7 & 28.7 turw & 3 & $981_{\mathrm{pqr}}$ \\
\hline $14-2-S \ldots \ldots \ldots$ & 3 & $24.0_{\text {stu }}$ & 3 & $23.8_{\mathrm{stu}}$ & 13 & 1264 tuvw \\
\hline $14-1-S \ldots \ldots$. & 4 & 28.1 tur & 9 & 30.2 tuvw $x$ & 10 & 1181 rstur \\
\hline $14-1-N \ldots$ & 5 & 28.6 tuv w & 17 & 36.9 tuvwxy & 2 & $961_{\mathrm{pq}}$ \\
\hline $10-5-S \ldots \ldots$ & 6 & 29.0 tur & 13 & 33.9 tuvw $x y$ & 5 & 1082 qrst \\
\hline $6-2-S \ldots \ldots$ & 7 & 29.0 tuvw & 2 & $21.9_{\mathrm{st}}$ & 26 & 1530 \\
\hline $14-3-S \ldots \ldots$ & 8 & 32.4 tuvwx & 8 & 29.4 tuvw x & 20 & uvwxy : \\
\hline $14-4-S$ & 9 & 33.1 tuvwxy & 10 & 31.0 tuvwx & 18 & 1332 uvwrye \\
\hline $6-1-\mathrm{N}$ & 10 & 33.3 tuvw xy & 4 & $25.5_{\text {stuv }}$ & 27 & 1542 \\
\hline $10-1-\mathrm{N}$ & 11 & 33.6 tuvwxy & 5 & $27.6 \mathrm{tuvw}$ & 24 & 1472 \\
\hline $6-3-\mathrm{N}$ & 12 & 33.7 tuvwxy & 12 & 32.4 tuvw x & 15 & uvw \\
\hline $6-5-N \ldots \ldots$ & 13 & 33.8 tuvwxy & 15 & 35.0 tuvwxy & 11 & 1212 stuvw \\
\hline $14-5-N \ldots \ldots$ & 14 & 34.1 tuvwxyz & 11 & 32.4 tuvwx & 17 & 1317 uvwxy \\
\hline $14-4-N$ & 15 & 35.9 tuvwxyz & 6 & 28.2 tuvw & 25 & 1527 \\
\hline 6-1-S. & 16 & 37.8 tuvwxyz & 16 & 36.1 tuvwxy & 16 & 1315 uvwxy \\
\hline $10-5-\mathrm{N}$ & 17 & 37.8 tuvwryz & 20 & 40.8 vwxyz & 8 & 1153 qristuv \\
\hline $10-2-\mathrm{S} \ldots$ & 18 & 37.9 tuvwxyz & 14 & 34.5 tuvw xy & 21 & $1369 \quad$ vwxy \\
\hline $6-5-\mathrm{S} \ldots$ & 19 & 38.1 tuvw $x y z$ & 22 & $44.8 \quad w x y z$ & 4 & $10^{9} 0_{\mathrm{pqrs}}$ \\
\hline $6-2-N \ldots$ & 20 & $41.6 \mathrm{uvw} x y \mathrm{z}$ & 19 & 40.3 uvw'xy z & 14 & uvw x \\
\hline $10-1-S \ldots$ & 21 & $42.7 \quad \mathrm{vwxyz}$ & 18 & 37.1 tuvwry & 23 & 1444 \\
\hline $10-4-S$. & 22 & 43.3 vwxyz & 23 & $46.2 \quad \mathrm{xyz}$ & 9 & 1162 qrstuv \\
\hline $10-3-\mathrm{N}$. & 23 & 43.4 vพxyz & 27 & $\mathbf{5 6 . 6}$ & 1 & $836_{p}$ \\
\hline $10-4-\mathrm{N}$ & 24 & $47.1 \quad$ wxyz & 21 & 42.4 vwxyz & 22 & wxy $z$ \\
\hline $6-4-N$ & 25 & 50.2 & 25 & 50.3 & 12 & 1253 tuvw \\
\hline $10-2-N \ldots$ & 26 & 51.5 & 26 & 55.0 & 6 & 1141 qrstu \\
\hline $14-2-N \ldots$ & 27 & 53.3 & 24 & 50.2 & 19 & 1360 uvwxy \\
\hline C.V.. & & 29 & & 26 & & 17 \\
\hline
\end{tabular}

* Means are significantly different at the .05 level if they do not have a subscript letter in common.

highly significant. In experiments in two other counties where differential fertilization had no or only slight effects on the variables studied, most of the simple correlations with creasing were nonsignificant. These data were subjected to multiple regression analyses (table 12). Analysis was made on the adjusted total line and on the error line. Error line analysis estimated results that would be expected if no differential treatment were applied. The " $t$ " values in table 12 provided the statistics for the tests of significance of the partial correlation coefficients. Those indicated as being significant were each significant when viewed as grouped into significant contributors and nonsignificant contributors, as illustrated in the table. The multipleregression analyses showed no clear, consistent results among the experiments. These data indicate that one or more primary causal variables, not measured in this study, were influencing the incidence of creasing. In the San Diego experiment, where differential $\mathrm{P}$ treatments had a great effect on the number of fruit per tree, the variable, "number of fruit per tree," was the most significant contributor to the multiple regression on the total line. Highly significant simple correlations of creasing with numbers of fruit per 
tree were found in data (not presented) from 55 out of 61 experiment years; lack of significance occurred where yields were low or where fertilizer treatment did not induce yield differences.

\section{A possible genetic factor in the creasing problem}

Data on ten years' creasing and yield relations from 27 trees that were treated uniformly are shown in table 13. Some of these trees were consistently high producers. Tree 6-2-S, for example, averaged 1,530 fruits per tree per year and had a mean unadjusted creasing percentage of 29 . In the numerical rank of creasing, this was the seventh lowest of the 27. Certain other high-producing trees also had relatively low creasing percentages. In these data the simple correlation $(r)$ between percentage of creasing and the number of fruits per tree was +0.559 (significant at the 0.1 level). This indicates that about 31 per cent of the variability in the creasing data can be attributed to variation in number of fruit per tree. When the percentage of creasing was adjusted, by covariance analysis, for numbers of fruit per tree, tree 6-2-S was numerically next to the lowest. Other high-producing trees were among the lowest group in adjusted creasing percentage. These data suggest that a genetic factor may be involved in the creasing problem, and that, by selection, highly productive strains could be obtained that would produce fruit with a relatively low incidence of creasing. Additional studies need to be conducted along these lines.

\section{LITERATURE CITED}

BAIN, JoAN M.

1958. Morphological, anatomical, and physiological changes in the developing fruit of the Valencia orange Citrus sinensis (L.) Osbeck. Aust. Jour. Bot. 6:1-24.

BARTholomew, E. T., and H. S. REeD

1946. Chap. VI, General Morphology, Histology, and Physiology. The Citrus Industry, Vol. I, Univ. of California Press, Berkeley.

Chapman, H. D., and D. S. RaYner

1951. Effect of various maintained levels of phosphate on the growth, yield, composition and quality of Washington navel oranges. Hilgardia $20(17): 325-58$.

Charnat, A.

1954. Rapport sur le gaufrage des oranges. Fruits et Primeurs de l'Afrique du Nort. Numero special No. $255(15): 147-64$.

Chevalier, Gaston

1952. La Boursouflure des agrumes. Fruits et Primeurs de l'Afrique du Nort. $22: 339-43$.

DUNCAN, D. B.

1955. Multiple range and multiple $\mathrm{F}$ tests. Biometrics 11:1-42.

Embleton, T. W., W. W. Jones, and J. D. KirkPatrick

1956. Influence of applications of dolomite, potash, and phosphate on quality, grade, and composition of Valencia orange fruit. Proc. Amer. Soc. Hort. Sci. 67:191-201.

Embleton, T. W., J. D. Kirkpatrick, W. W. Jones, and C. B. Cree

1956. Influence of applications of dolomite, potash, and phosphate on yield and size of fruit and on composition of leaves of Valencia orange trees. Proc. Amer. Soc. Hort. Sci. $67: 183-90$.

Embleton, T. W., J. D. Kirkpatrick, and E. R. Parker

1952. Visible response of phosphorus-deficient orange trees to phosphatic fertilizers, and seasonal changes in mineral constituents of leaves. Proc. Amer. Soc. Hort. Sci. 60:55-64.

Fourie, S., and G. F. JouberT

1957. Effect of potash and phosphate on yield and creasing of navel oranges in the Citrusdal area. Citrus Grower (South Africa) 277:1-3.

HaAs, A. R. C.

1950. The relation of phosphorus to creasing and puffing in Valencia oranges. California Citrog. $35: 277-78,298-300$. 
Jones, W. W., T. W. Embleton, and C. B. Cree

1957. Number of replications and plot sizes required for reliable evaluation of nutritional studies and yield relationships with citrus and avocado. Proc. Amer. Soc. Hort. Sci. $69: 208-16$.

Le Roux, J. C., and P. A. Crous

1938. Effect of fertilizer on creasing of Mediterranean sweet oranges. Farming in South Africa 13:66-68, 85 .

LOMBARD, P. B.

1963. Late harvested fruit of Valencia strains compared. California Citrog. 48:139-40.

MILLER, E. V.

1945. Some observations on creasing in Florida oranges. Proc. Florida State Hort. Soc. $58: 159-60$.

Miller, E. V., and J. Turnbull

1948. Relation of irrigation to creasing in oranges in Florida. Citrus Industry (Florida) $29(4): 16-17$.

Pelton, S. D.

1907. Mimeographed reports, addresses, and suggestions relative to the Experiment Station at Riverside, California, and the Pathological Institute at Whittier, California. Special Citrus Fruit Growers Institute. Bureau of Farmers Institutes. Edited by Ralph E. Smith, University of California (Berkeley).

ReITz, H. J., and R. C. J. Koo

1960. Effect of nitrogen and potassium fertilization on yield, fruit quality, and leaf analysis of Valencia orange. Proc. Amer. Soc. Hort. Sci. 75:244-52.

Reuther, W., and P. F. SMith

1952. Relation of nitrogen, potassium, and magnesium fertilization to some fruit qualities of Valencia oranges. Proc. Amer. Soc. Hort. Sci. 59:1-12.

Sites, J. W., and E. J. Deszyck

1952. Effect of varying amounts of potash on yield and quality of Valencia and Hamlin oranges. Proc. Florida State Hort. Soc. 65:92-98.

SNEDECOR, G. W.

1940. Statistical methods. Iowa State College Press, Ames, Iowa.

VAN NIEKERK, O. T.

1955. Report on Activities of the South Africa Co-operative Citrus Exchange Field Department, May, 1955. Citrus Grower (Africa) 257:7-9, 12.

\section{ACKNOWLEDGMENT}

We wish to acknowledge the cooperation of Hartwell Bradford, Henry Grenfell, and Stanley Socha (all deceased); E. L. Barnhart, A. S. Bradford, Volney H. Craig, Jr., Ray Easton, Fred Foote, Kenneth Glenn, John Guinther, Allen Lombard, Lawrence Mason, Owen Murray, and Minor Warne.

We also wish to thank Citrus Research Center personnel: Mrs. Eleanor Beckwith, Robert Hildebrandt, Dr. J. D. Kirkpatrick, Dr. C. K. Labanauskas, Mitsuo Matsumura, and M. L. Steinacker. 


The journal HILGARDIA is published at irregular intervals, in volumes of about 650 to 700 pages. The number of issues per volume varies.

Single copies of any issue may be obtained free, as long as the supply lasts; please request by volume and issue number from:

\author{
Agricultural Publications \\ University Hall \\ University of California \\ Berkeley, California $\mathbf{9 4 7 2 0}$
}

The limit to nonresidents of California is 10 separate titles. The limit to California residents is 20 separate titles.

The journal will be sent regularly to libraries, schools, or institutions in one of the following ways:

1. In exchange for similar published material on research.

2. As a gift to qualified repository libraries only.

3. On a subseription basis $\$ 7.50$ a year paid in advance. All subscriptions will be started with the first number issued during a calendar year. Subscribers starting during any given year will be sent back numbers to the first of that year and will be billed for the ensuing year the following January. Make checks or money orders pay. able to The Regents of The University of California; send payment with order to Agricultural Publications at above address. 